\title{
Observation of Canna lily for Phytotechnology in Constructed Wetland
}

\author{
Ram Babu Pachwarya ${ }^{1}$, Euis Nurul Hidayah ${ }^{2}{ }^{*}$, Rizka Novembrianto ${ }^{2}$, Yuliatin Ali Syamsiah ${ }^{2}$ \\ ${ }^{1}$ Department of Chemistry, Motilal Nehru College, Universitas of Delhi, New Delhi, India \\ ${ }^{2}$ Department of Enviromental, Engineering, Universitas Pembangunan Nasional “Veteran' Surabaya, East \\ Java, Indonesia
}

*Corresponding author:

E-mail: euisnh.tl@upnjatim.ac.id

\begin{abstract}
The application of sewage treatment in New Delhi should implement the treatment processes, which are easy to be operated and is not costly operational and avoid the complexity of the operating system of STP. The renewed interest in alternative onsite treatment technology by using a constructed wetland (CW). Canna lily, an ornamental plant that has an aesthetic value, is very suitable for an alternative plant for a constructed wetland. This study aims to observe the ability of canna lily for phytotechnology implementation in a constructed wetland. This study is known as a range-finding test (RFT), which served as a preliminary test. Observation is conducted by preparing variation concentration of wastewater; $25 \% ; 50 \% ; 75 \% ; 100 \%$ and $0 \%$ as control, which was injected into the wetland. CW $(60 \mathrm{~cm}$ long, $60 \mathrm{~cm}$ wide and $60 \mathrm{~cm}$ deep) contained gravel medium height $25 \mathrm{~cm}$ with a wastewater volume $3 \mathrm{~L}$. Observation measured the height of the plant, the color of the leaf, and DO, and BOD concentration. The observation was conducted for about 25 days, in term of 15 days for range finding test and 10 days for acclimation. The results show that Canna lily could grow well, though it has some part of the withered leaf, reach height significantly, and indicated decreasing concentration of organic parameters. It is conjectured that Canna lily is very possible for a constructed wetland application.
\end{abstract}

Keywords: Range-finding test, constructed wetland, plant, acclimation

\section{Introduction}

The application of sewage treatment in New Delhi should implement the treatment processes, which are easy to be operated and is not costly operational and avoid the complexity of the operating system of STP. The renewed interest in alternative onsite treatment technology by using a constructed wetland (CW). CW represents one alternative technology that may address more stringent nutrient removal standards while providing relatively low maintenance requirements and capital and operating costs. CW, a green treatment technology by simulating natural wetlands, has been widely used to treat various kinds of wastewater such as domestic sewage, agricultural wastewater, industrial effluent, mine drainage, landfill leachate, stormwater, polluted river water, and urban runoff in the last few decades (Akizuki, Nagao, \& Toda, 2018; Priya \& Selvan, 2017). Different types of plants can be grown in the system constructed wetland. The type of plants can be adjusted according to the type the wetland system used. Also, many plants are easy for adapting to this system. Canna lily, an ornamental plant that has an aesthetic value, is very suitable for an alternative plant for SSF constructed wetland.

Canna lily has a large root system and strong enough to absorb organic matter, therefore, Canna lily can absorb more nutrients for growth and store the excess nutrient in its tissue than other aquatic plants (Yadav, Chazarenc, \& Mutnuri, 2018). CWs system operating as standalone technologies are in some cases unable to meet the requirements of these new guidelines despite

\section{How to cite:}

Pachwarnya, R. B., Hidayah, E. U., Novembrianto, R., \& Syamsiah, Y. A. (2020). Observation of Canna lily for phytotechnology in constructed wetland . 1 ${ }^{\text {st }}$ International Conference Eco-Innovation in Science, Engineering, and Technology. NST Proceedings. pages 34-40. doi: 10.11594/ nstp.2020.0504 
improvements in design and operational strategies and the utilization of intensified systems such as flow direction reciprocation, artificial aeration, tidal flow CWs (Haritash, Duta, \& Sharma, 2017). Therefore, combining or integrating CWs with other existent or emerging technologies. This study aims to observe the ability of canna lily for phytotechnology implementation in a constructed wetland. This study is known as a range-finding test (RFT), which served as a preliminary test. It is performed to determine the extent to which the plant was able to absorb pollutants at certain concentrations.

\section{Material and Methods}

In aquatic range-finding tests, groups of selected organisms are exposed to test materials under defined conditions to determine potential adverse effects. This stage is conducted by preparing variation concentration of wastewater; $25 \% ; 50 \% ; 75 \% ; 100 \%$ and $0 \%$ as control, which was injected into the wetland. CW ( $60 \mathrm{~cm}$ long, $60 \mathrm{~cm}$ wide and $60 \mathrm{~cm}$ deep) contained gravel medium height $25 \mathrm{~cm}$ with a wastewater volume $3 \mathrm{~L}$. Constructed wetlands planted with Canna lily, one plant per chamber. USEPA Guidelines Part OPPTS 850.4400 states that many concentrations varied in the RFT stage of 5 concentrations over 15 days. The batch process of RFT observed the parameters of plant growth, at which concentration the plant remains fresh (does not wither and die) and that selected concentration will be applied for photo treatment experiment. The further stage in plant acclimation to adapt Canna lily to the environmental conditions that will be adjusted according to the research design. The conditioning was carried out for ten days after the plants were released from the growing media during the nursery and planted in the constructed wetland (Hidayah et al., 2020).

\section{Results and Discussion}

The range finding test was conducted in 15 days by observing the growth daily for the first day and every one day after, as shown in Table 1 . There were no significant changes on five days after. The withered plant was detected at the end of the range finding a test with a BOD concentration of $200 \mathrm{mg} / \mathrm{L}$. The percentage of the withered plant after 5 days due to high loading organic exposure are summarized in Table 4.1. The results indicated that the withered plant in 50\% BOD concentration has been detected from the nursery, though only $10 \%$ area of a leaf and the withered leaf became $30 \%$ area of a leaf.

The green color of a leaf in 25\% BOD concentration shifted into yellowish about $10 \%$ area of a leaf, after a day and increased into $20 \%$ yellowish leaf. The withered plant in $100 \%$ BOD concentration occurred about 50\% after 5 days. According to the DO concentration, it seems that the constructed wetland has low DO, and BOD decreases simultaneously. It indicated that the system is lack of oxygen due to microorganism, which lived as attached biofilm on the gravel, uptakes oxygen to degrade organic material (Avila, et al., 2019).

The withered leaf indicated that plants more sensitive to stages of a particular organic concentration (Abou-Elela \& Hellal, 2012). However, the withered leaf occurred in a particular leaf, it could be indicated that the plant was adapting in the extreme concentration (Chazarenc, Gagnon, \& Korkusuz, 2015). Besides, the height of the plant increased on average $7.6 \mathrm{~cm}$, and most of the plant generated 1 cotyledon after 5 days. The range finding test conjectured that the sample for the experimental constructed wetland treatment process is pure fresh wastewater from inlet wastewater, without dilution concentration. 
Table 1. Range finding test for canna lily

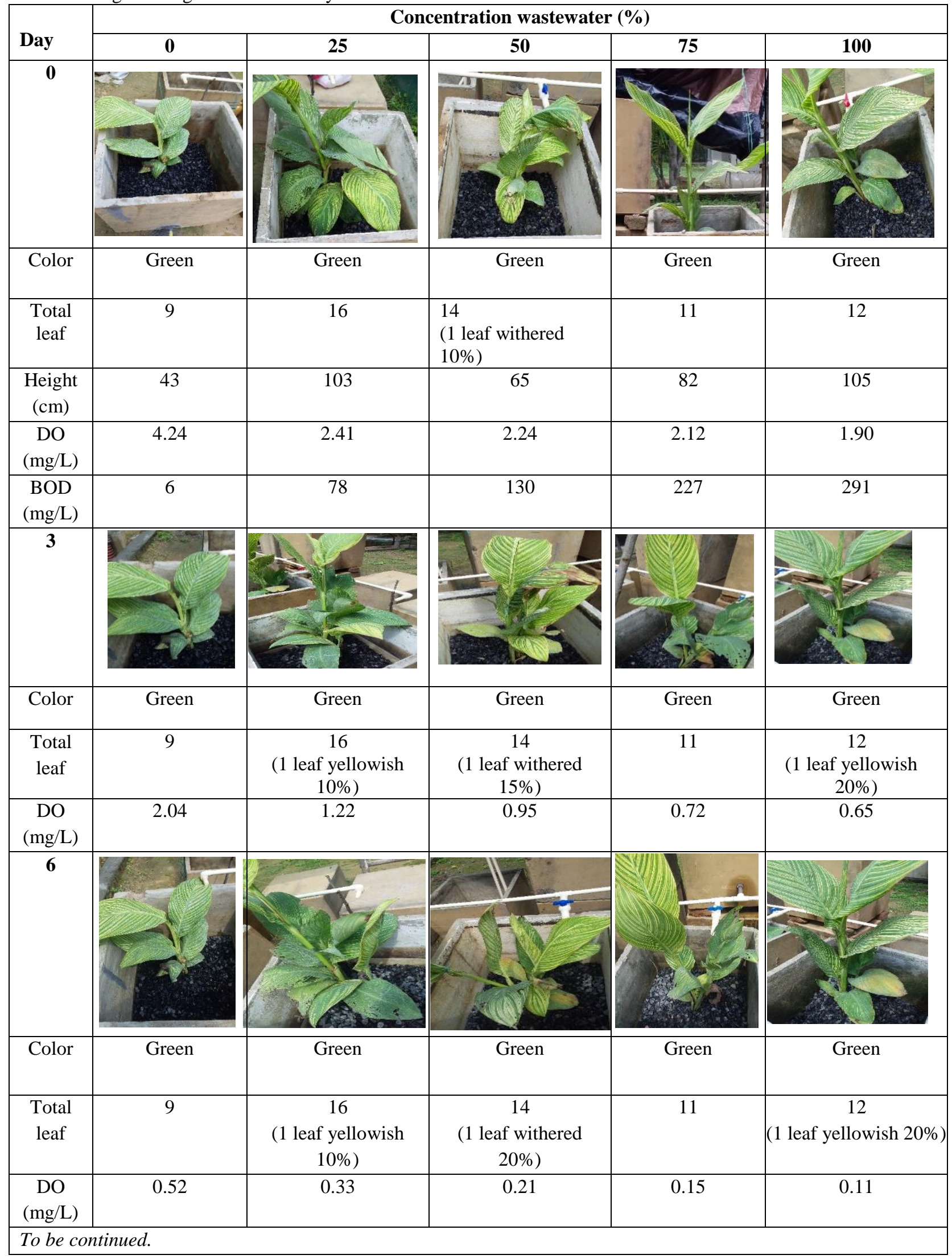




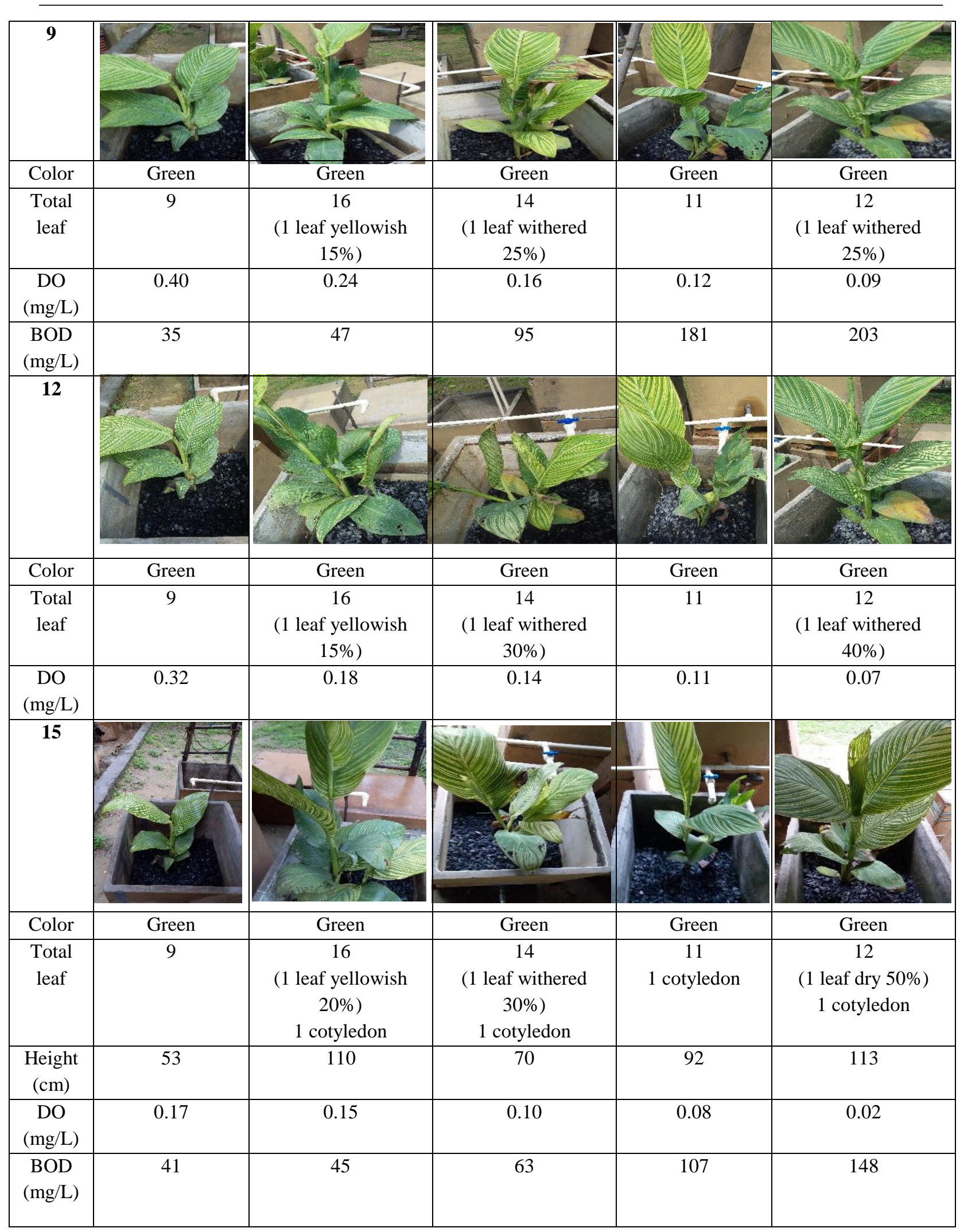


Plant acclimatization takes place over ten days with the following divisions:

a. First two days, the plants in the constructed wetland were watered with clean water until the water was discharged to the outlet pipe. It was performed three times per day for two days.

b. In the second three days, the plants in the constructed wetland were watered with wastewater until the water was discharged to the outlet pipe. It was performed once per day in the afternoon for three days.

c. Last five days, the plants in the constructed wetland were watered with wastewater until the water was discharged to the outlet pipe. It was performed three times per day for 2 days. The following days, plants in the constructed wetland were watered with wastewater until the water level was below the gravel, or it was a batch process and performed daily for 3 days.

At the end of the acclimatization process, it should be ensured that the plant and constructed wetland were still suitable for implementing research: no disease-affected plants and the flow inside the reactor is smooth. The results are shown in Table 2.

Table 2. Plant acclimation

\begin{tabular}{|c|c|c|c|c|c|c|c|}
\hline \multirow[t]{2}{*}{ Day } & \multirow[t]{2}{*}{ Watering } & \multicolumn{2}{|c|}{ Chamber Code } & \multirow[t]{2}{*}{ Day } & \multirow[t]{2}{*}{ Watering } & 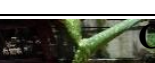 & er Code \\
\hline & & 1 & 2 & & & & 2 \\
\hline \multirow[t]{4}{*}{0} & Clean & & & 6 & & & \\
\hline & Color & Green & Green & & Color & Green & Green \\
\hline & Total leaf & $9+0 / 12+1$ & $16+1 / 11+1$ & & Total leaf & $9+1 / 13+1$ & $17+0 / 11+1+1$ \\
\hline & $\begin{array}{l}\text { Height } \\
(\mathrm{cm})\end{array}$ & $53 / 113$ & $110 / 92$ & & $\begin{array}{l}\text { Height } \\
(\mathrm{cm})\end{array}$ & & \\
\hline \multirow[t]{5}{*}{1} & Clean & & & 7 & & & \\
\hline & $3 x /$ day & & & & & & \\
\hline & Color & Green & Green & & Color & Green & Green \\
\hline & Total leaf & $9+0 / 12+1$ & $16+1 / 11+1$ & & Total leaf & $9+1 / 13+1$ & $17+0 / 12+1$ \\
\hline & $\begin{array}{l}\text { Height } \\
(\mathrm{cm})\end{array}$ & & & & $\begin{array}{l}\text { Height } \\
(\mathrm{cm})\end{array}$ & & \\
\hline \multirow[t]{5}{*}{2} & Clean & & & 8 & & & $c^{5}$ \\
\hline & $3 x /$ day & & & & & & \\
\hline & Color & Green & Green & & Color & Green & Green \\
\hline & Total leaf & $9+0 / 12+1+1$ & $16+1 / 11+1$ & & Total leaf & $9+1 / 13+1$ & $17+0 / 12+1$ \\
\hline & $\begin{array}{l}\text { Height } \\
(\mathrm{cm})\end{array}$ & & & & $\begin{array}{l}\text { Height } \\
(\mathrm{cm})\end{array}$ & & \\
\hline
\end{tabular}




\begin{tabular}{|c|c|c|c|c|c|c|c|}
\hline 3 & Wastewater & & & 9 & & & \\
\hline & Color & Green & Green & & Color & Green & Green \\
\hline & Total leaf & $9+0 / 12+1+1$ & $16+1 / 11+1$ & & Total leaf & $9+1 / 13+1$ & $17+0 / 12+1$ \\
\hline & $\begin{array}{l}\text { Height } \\
(\mathrm{cm})\end{array}$ & & & & $\begin{array}{l}\text { Height } \\
(\mathrm{cm})\end{array}$ & & \\
\hline 4 & $\begin{array}{l}\text { Wastewater } \\
1 \mathrm{x} / \mathrm{day}\end{array}$ & & & 10 & & & \\
\hline & Color & Green & Green & & Color & Green & Green \\
\hline & Total leaf & $9+0 / 12+1+1$ & $16+1 / 11+1+1$ & & Total leaf & $10+0 / 13+1$ & $17+1 / 12+1$ \\
\hline & $\begin{array}{l}\text { Height } \\
(\mathrm{cm})\end{array}$ & $60 / 117$ & $114 / 97$ & & $\begin{array}{l}\text { Height } \\
\text { (cm) }\end{array}$ & $75 / 124$ & $121 / 105$ \\
\hline 5 & & & & & & & \\
\hline & Color & Green & Green & & & & \\
\hline & Total leaf & $9+1 / 13+1$ & $16+1 / 11+1+1$ & & & & \\
\hline & $\begin{array}{l}\text { Height } \\
(\mathrm{cm})\end{array}$ & & & & & & \\
\hline
\end{tabular}

\section{Conclusion}

This study concluded that Canna lily could be implemented as phytotechnology for constructed wetlands, as the results indicated all plants grow well. Even though some part of the plants was showing a withered leaf, the height of the plant increased during the time growth, and organic parameters indicate a fluctuating concentration. Besides, Canna lily could be adapted to the environmental conditions, in case Canna lily had survived in domestic wastewater during acclimation processes

\section{Acknowledgment}

Praise be to God Almighty for giving His grace and guidance so that this journal can be completed properly. And we also thank Mrs. Euis Nurul Hidayah ST., MT., Ph.D. because she is the one who always helps and provides direction. As well as colleagues who are good at working together and giving encouragement.

\section{References}

Abou-Elela, A.I., \& Hellal, M.S. (2012). Municipal wastewater treatment using vertical flow constructed wetlands planted with Canna, Phragmites and Cyprus. Ecological Engineering, 47, 209-213.

Akizuki, S., Nagao, N., \& Toda, T. (2018). A multifunctional single-stage process for the effective methane recovery and denitrification of intermittently discharged wastes. International Biodeterioration and Biodegradation, 127, 201-208.

Avila, F.G., Chavez, J.P., Chimbo, F.Z., Moscoso, S.D., del Pino, L.F., \& Anazco, A.A. (2019). Performance of phragmites australis and cyperus papyrus in the treatment of municipal wastewater by vertical flow subsurface constructed wetlands. International Soil and Water Conservation Research, 7(3), 286-296. 
Chazarenc, F., Gagnon, V., \& Korkusuz, E.A. (2015). Treatment of pollution in constructed wetlands: from the fundamental mechanisms to the full-scale applications. Environmental Science and Pollution Research, 22(17), 12775-12778.

Haritash, A.K., Dutta, S., \& Sharma, A. (2017). Phosphate uptake and translocation in a tropical Canna-based constructed wetland. Ecological Processes, 6(12), 1-7.

Hidayah, E.N., Pachwarya, R.B., Cahyonugroho, O.H., \& Ramanathan, A.L. (2020). Characterization of molecular weight-based fluorescent organic matter and its removal in combination of constructed wetland with activated sludge process. Water, Air, Soil Pollution, 231(41).wetland. Bioresource Technology, 162, 166-174.

Priya, E.S., \& Selvan, P. S. (2017). Water hyacinth (Eichhornia crassipes)-an efficient and economic adsorbent for textile effluent treatment-a review. Arabian Journal of Chemistry, 10, S3548-S3558.

Yadav, A., Chazarenc, F., \& Mutnuri, S. (2018) Development of the «French system» vertical flow constructed wetland to treat raw domestic wastewater in India. Ecological Engineering, 113, 88-93 